\title{
The Concept of Reforming Russian Legislation Due to Digitization Processes
}

\author{
Valentina Moiseeva ${ }^{1, *}$ Vera Romanova $^{1}$ Irina Popryadukhina ${ }^{1}$ \\ ${ }^{1}$ Togliatti State University, Togliatti 445020, Russian Federation \\ "Corresponding author. Email: upik85@yandex.ru
}

\begin{abstract}
The relevance of the concept of reforming Russian legislation is due to digitalization processes that permeate all areas of public life. In modern legal reality, new legal phenomena appear in the form of subjects and objects of legal regulation. Legal relations arising in the field of digital technologies are also distinguished by certain specifics. Despite the steps taken by the legislator, in general, the current legislation in the context of digitalization is characterized by a high degree of uncertainty. To this day, there are no legal basic terms related to the technologies of intelligent systems and artificial intelligence. In this connection, one of the tasks of modern legal reality is the creation of a system of legal regulation in the context of digitalization of public relations. The solution to this problem is possible only through the development of the conceptual framework for reforming Russian legislation, due to digitalization processes. And only within the framework of the concept of reforming Russian legislation in the context of digitalization can we talk about a more detailed conceptual legal regulation of Russian legislation in relation to certain types of activities.
\end{abstract}

Keywords: Digitalization, digitalization of the legal system, digital economy, digital law, digital space, digital environment, intelligent system, artificial intelligence.

\section{INTRODUCTION}

Currently, when the online and offline spheres merge, the cyber-physical world appears and such an objectively new phenomenon as "Industry 4.0 " is formed, characterized by the creation and integration of new digital technologies, more and more we have to talk about the "digital revolution" [1-5], "which is based on the digitalization of production and social processes" [6].

Digital solutions and intelligent systems permeate all spheres of social life. The volume of the artificial intelligence market is growing. Among the current trends, experts call the development of adaptive functions of artificial intelligence, the integration of digital intelligent technologies in education, medicine, banking, the creation of multifunctional intelligent systems, the improvement of robotics [7, pp. 35-37]. Information and analytical systems are increasingly being introduced into legal activity, the use of information systems in the service sector and in everyday life is becoming more active. In the future, it is assumed that robotic services, which are gaining momentum today, will become trends in the digital and artificial intelligence market. Thus, robotic lawyers are increasingly used, which are able to draw up statements of claim, claims, and draw up contracts. Artificial intelligence is also capable of performing some of the functions of a notary in terms of checking transactions for compliance with laws. Increasingly, interaction with the judiciary is shifting to the online sphere. Through the Internet, you can submit an application to the arbitration court and some district courts. Discussion of issues on reducing law enforcement to the "blockchain" procedure and automated consideration of some simple categories of cases, i.e. using artificial intelligence [8, pp. 277-281]. Since 2018, the legal consulting service "Pravoved" provides an opportunity to use the services of a robotic lawyer, who have considered over a million issues in two years, which served as the basis for the accumulation and creation of a consulting algorithm. All this speeds up the time-of-service provision, and also makes the price for this type of service cheaper [9, pp. 53-60].

\section{LEGAL SYSTEM DIGITALIZATION}

For modern legal reality, there is a tendency for the emergence of new legal phenomena associated with the digitalization of many spheres of public life. In particular, we are talking about the emergence of new subjects (virtual (digital) personalities, as a digital image of cyberspace participants [10, pp. 18-19]) and objects of legal regulation (cryptocurrency), differ in certain specificity and legal relations in the field of digital technologies. New concepts and categories come into use, such as, for example, "digital economy", "digital law", "digitalization of the legal system", "digital rights of subjects of legal relations", etc. In this connection, the doctrine increasingly raises the question of the need to form digitalization of the legal system [10, 20 p.], digitalization in the context of law [11, $6 \mathrm{p}$.], legal regulation of digital environments, digital spaces, regulation of the 
circulation of impersonal information [12, 220 p.]. In general, one should agree that digitalization of law makes a challenge to the law itself [13, pp. 5-17].

All of this predetermined the next steps in the legal regulation of the digital environment based on some policy documents.

First of all, in 2017, the President of the Russian Federation approves the Strategy for the Development of the Information Society in the Russian Federation for 2017 - 2030 [14]. This Strategy defines the goals, objectives and measures aimed at the development of the information society and the formation of the digital economy.

Further, the Order of the Government of the Russian Federation approves the program "Digital Economy of the Russian Federation" [15], which is also aimed at creating the necessary conditions for the development of the digital economy in the Russian Federation. In this Program, among the basic directions of development, were named, in particular, legal regulation, information infrastructure and information security.

However, since February 12, 2019, this Program has ceased to be in force [16].

On February 15, 2019, at the Russian Innovation Forum, problems were identified that hindered the implementation of the federal program "Digital Economy of the Russian Federation". This is, first of all, the slow process of adopting laws, resistance to innovation, and the intersectoral and cross-border nature of the digital economy create regulatory difficulties. Indeed, at present, sectoral regulation ceases to be only sectoral, a lot of attention is paid to related regulation, and the sectors are beginning to intertwine with each other. And this causes a certain imbalance in the existing system of relations, including legal [17].

The forum participants suggested the following possible solutions to the above problems:

1) creation of regulatory "sandboxes", i.e. a legal experiment that allows technologies provided by the digital economy to get out of the existing regulatory regulation and spend some time in the created "sandbox" and, in the process, develop new rules and tools for soft regulation;

2) introduction of a consent mechanism for data processing;

3 ) the use of digital technologies in the very process of regulation, i.e. creation of a platform on which drafts of normative legal acts could be created in the wiki mode, and at the same time this would be the will of the authorities; [17].

4) involvement of business in the legislative process

In general, the participants in the form came to such key conclusions as:

1) regulation must be adapted to the digital economy through regulatory flexibility;
2) smart regulation aims to bridge the gap between laws and their application. According to Shklyaruk, "the development of "smart" regulation is based on several key points that should reduce the gap between what we enshrine in regulatory acts and what we implement in practice" [17].

Currently, the national project of the National Program "Digital Economy of the Russian Federation", approved by the Presidium of the Council under the President of the Russian Federation for Strategic Development and National Projects on June 4, 2019 [18], is in force, in which some of the issues identified at the forum were taken into account. The structural element of this national program is the federal draft of legal regulation of the digital environment [19], which is designed to form the regulatory prerequisites for the development of the digital environment and to solve numerous problematic issues related to the development of the digital environment.

\section{NORMATIVE REGULATION OF THE DIGITAL ENVIRONMENT}

Analysis of the federal project "Normative regulation of the digital environment" allows us to single out several priority bills, which can be conditionally divided into several blocks.

The first block of bills involves the creation of a unified digital environment of trust by clarifying the legal status of certification centers, establishing unified requirements for a unified qualified digital signature and expanding the capabilities and methods of identification in order to eliminate legal restrictions and expand the use of electronic signatures. Several bills have already been developed on this issue [20], [21].

The second block of bills should be aimed at creating electronic civil circulation by clarifying existing and defining new requirements for the forms of transactions, as well as the formation of a procedure for storing electronic documents, creating, storing and using electronic duplicates (electronic samples) of paper documents. So, from October 1, 2019, Federal Law No. 34FZ of March 18, 2019 introduces a new rule on the written form of a transaction, which will be considered complied with if it is made through electronic or other technical means [22].

The third block of bills is the legal regulation of data circulation aimed at improving the procedure for working with consent, establishing the procedure for depersonalizing personal data, conditions and procedures for their use, as well as liability for improper processing, the procedure for obtaining consent to the processing of personal data.

The fourth block assumes the regulation of the circulation of digital financial assets (the procedure for issuing, accounting, circulation and storage of digital 
rights), as well as determining their legal status. On this issue, the Russian Ministry of Finance has developed a draft federal law No. 419059-7 "On digital financial assets" [23].

The fifth block of bills provides for a number of incentive measures, including tax in part:

- $\quad$ establishing the conditions for the

taxation of VAT on operations for the export of works, services, similar to the conditions for the taxation of operations on the export of goods;

- tax incentives for private investors investing in Russian high-tech projects.

The sixth block of bills should be aimed at the formation of legal regulation of legal proceedings in terms of unification of the rules for filing in electronic form of claims, complaints, petitions, regulation of the admissibility of electronic evidence and remote participation in the court session. In addition, in the field of notaries, it is planned to develop tools for electronic notaries (production of notarial documents in electronic form, remote execution of notarial actions, etc.).

The seventh block of bills is to ensure legal regulation of digital interaction between the entrepreneurial community and the state in terms of recording information about the employee's labor activity in electronic form ("electronic work record book") and concluding, changing, terminating and storing employment contracts, introducing personnel document management in electronic form. For example, the Ministry of Labor of Russia has developed bills proposing changes to the current labor legislation in terms of the formation and maintenance of information about the employee's labor activity in electronic form (electronic work record book) [24], as well as about conducting an experiment on maintaining electronic documents related to work stipulated by labor legislation [25].

The eighth block of legislation is the legal regulation of legal relations in the field of robotics and the use of artificial intelligence technologies. In particular, the Ministry of Economic Development of Russia has developed a draft law aimed at determining the procedure for initiating, establishing, implementing, monitoring implementation, determining the results of the implementation of experimental legal regimes in the field of digital innovations, consisting in the temporary targeted controlled establishment of a special regulatory legal regulation for the use of digital innovations or carried out with them. use of activities in the Russian Federation [26].

The ninth block of bills is the regulation of the effective use of the results of intellectual activity in the digital economy. Thus, the Ministry of Education and Science of the Russian Federation has developed bills aimed at legal regulation of the rules for the circulation of rights to computer programs and databases in accordance with the needs of the digital economy [27], as well as to establish regulatory provisions that provide the possibility of forming shares in the exclusive right to the results of intellectual activity and means of individualization and their participation in civil circulation, the introduction of legal mechanisms to protect the interests of rightsholders when disposing of shares in the exclusive right by one of the rightsholders, as well as taking into account the interests of other participants in the civil turnover who enter into relations with rightsholders [28].

The tenth block of draft laws is aimed at introducing the use of innovative technologies in the financial market by defining the procedure and form of carrying out crowdfunding activities. On this issue, the Ministry of Economic Development has prepared a draft law designed to regulate relations on attracting investments by commercial organizations or individual entrepreneurs using information technologies, and also determines the legal basis for the activities of operators of investment platforms to organize retail financing (crowdfunding) [29].

The eleventh block of bills should regulate the creation and functioning of special legal regimes in the digital economy, the so-called "regulatory sandboxes".

The twelfth block of draft laws presupposes a comprehensive reform of legislation in the field of standardization in order to increase the competitiveness of Russian technologies and Russian business through the use of the results of computational experiments during conformity confirmation procedures.

In addition to the above blocks, there are other priority tasks. For example, this is an amendment to the EAEU law in terms of removing legal restrictions for the development of the digital economy. In addition, it is planned to introduce a mechanism for the formation and use of machine-readable norms, artificial intelligence technologies, processing big data and other technologies in order to automate and improve the efficiency of the law enforcement system.

As for the conceptual reform, it is planned to develop two concepts that adapt "existing regulation tools to the changing reality and set a new coordinate system for regulating the digital environment" [30], these are:

The concept of comprehensive legal regulation of relations in the digital economy;

- $\quad$ The concept of organizing the process of managing changes in the regulation of the digital economy, providing for the expansion of the activities of the federal project, including by giving flexibility to the legal regulation of the digital economy by other branches of legislation.

It is assumed that the development and adoption of the above bills will help remove the priority regulatory barriers that impede the development and functioning of the digital economy in the listed areas of public relations. As a result of the removal of priority regulatory 
barriers and the implementation of complex promising measures, a system of regulatory regulation will be created that will make it possible to promptly:

1) Identify regulatory problems, including regulatory gaps, excessive regulation, regulatory conflicts and others,

2) Develop, discuss the necessary management decisions and simulate their impact on public relations,

3) Formalize management decisions in the texts of draft regulatory legal acts and discuss them,

4) Adopt regulatory legal acts,

5) Monitor the practical implementation of decisions and regulatory legal acts,

6) Make the necessary adjustments.

As you can see, the legislator pays attention to the legislative regulation of the digital economy, while digitalization covers almost all areas of human activity, and not just the economic one. Modern legal regulation is directed towards the traditional legal system, not digital. The current legislation can be applied or partially applied in the context of digitalization. At the same time, there are separate normative legal acts that are specially created to regulate certain social relations in a digital format. However, there are not many such normative legal acts and they mainly regulate electronic document circulation, electronic commerce.

The current state of Russian legislation in the context of digitalization, despite the steps taken by the legislator, is generally characterized by a high degree of uncertainty. It is very difficult to give an objective assessment of the planned bills, the adoption of which is due to the digitalization of many spheres of human life, the possible consequences of their adoption and impact on public relations. To prepare a legal basis for the digitalization of public relations, deep and systematic work is required to develop legal institutions, to establish the relationship between new ones and existing legal categories and concepts. However, to this day, the current legislation does not establish the basic terms associated with intelligent systems technologies and artificial intelligence.

The development of the regulatory environment depends on the quality of legal regulation, which can also become an insurmountable barrier. The challenge now is to create a modern system of legal regulation in the context of digitalization of public relations. An important direction of improving the rule-making system is the use of the potential of using information technologies and special platform solutions [17].

The tendencies and conditions indicated above suggest the need to change the legal regulation of the digital environment through the formation of a "regulatory environment that provides a favorable legal regime for the emergence and development of intelligent digital systems" [7, 40 p.], as well as for the effective implementation of not only economic, but state and sociocultural activities on their basis. In this connection, a concept of comprehensive reform of Russian legislation is required, due to the digitalization processes. At the same time, a distinction should be made between digitalization as a process, meaning "the transition to a digital method of communication, recording and transmission of data using digital devices" [31] and digitalization of law, considered as a tool for auditing the quality of law, i.e. "Identification of outdated, non-working, as well as ineffective and ambiguous norms in the general array of legal acts and acts of law enforcement" [32, 38 p.]. The first concept is broader than the second. Speaking about the concept of reforming Russian legislation due to digitalization processes, we are talking about digitalization as a process that affects all spheres of human life that need legal regulation both in full and in terms of making appropriate changes and additions to the current legislation.

\section{CONCLUSIONS}

All in all, it appears that the concept of comprehensive reform of Russian legislation in the context of digitalization should provide for the following:

1) Basic principles for the development of legal regulation in the context of digitalization;

2) The main categories and concepts in the field of digitalization of public relations;

3) Features of digitalization of certain spheres of public relations (state, economic, social, cultural);

4) The main directions of development of the regulatory and legal framework in the field of digitalization in relation to certain areas of public relations.

Thus, within the framework of the concept of reforming Russian legislation in the context of digitalization, we can talk about a more detailed conceptual legal regulation of Russian legislation in relation to certain types of activities, and, in particular, complex legal regulation of relations in the digital economy.

\section{REFERENCES}

[1] P. Petrosyan (2018) My na poroge tsifrovoy revolutsii v sisteme zakupok. https://fas.gov.ru/news/24844 Accessed 25 Aug 2019

[2] M.A. Rozhkova, Pravo v sfere Interneta, Statut, 2018, 528 p.

[3] V. Rumak, Reforma korporativnogo prava v Rossii prodolzhaetsa (intervyu s A.K. Nesterenko), Zakon 1 (2019) 8-17.

[4] A.D. Selyukov, Tsifrovaya ekonomika kak obyekt finansovo-pravovogo obespecheniya v Rossiyskoy Federatsii (konceptualnye aspekty), Finansovoye pravo 10 (2018) 19-24. 
[5] S.S. Tropskaya, Finansovy rynok v usloviyakh razvitiya tsifrovoy ekonomiki (finansovo-pravovoy aspekt), Finansovoye pravo 8 (2018) 28-33.

[6] V.A. Vaypan, M.A. Egorova (Eds.), Pravovoye regulirovaniye ekonomicheskykh otnosheniy $\mathrm{v}$ sovremennykh usloviyakh razvitiya tsifrovoy ekonomiki, Yusticinform, 2019, $376 \mathrm{p}$.

[7] A.V. Dolmatov, L.V. Dolmatova, Tendencii organizacionnogo I normativnogo regulirovaniya tsifrovoy sredy, Vestnik SYuA 2(43) (2019) 35-43.

[8] D.S. Zuev, A.A. Marchenko, A.F. Khasiannov, Text Mining Tools in Legal Documents, in: L.A. Kalinichenko, Y. Manolopoulos, N.A. Skvortsov, V.A. Sukhomlin (Eds.), Data Analytics and Management in Data Intensive Domains, Collection of Scientific Papers of the $19^{\text {th }}$ International Conference (DAMDID/ RCDL'), MSU, Moscow, 2017, pp. 277-281.

[9] A.V. Dolmatov, Osobennosti I problemy pravovogo regulirovaniya zaschity personalnykh dannykh, Vestnik SyuA 3(40) (2018) 53-60.

[10] A. Karzhia, G. Makarenko, M. Sergin, Modern Trends of Cyber-Threats and Transformation of the Concept of Cybersecurity in the Conditions of Digitalization of the System of Law, Voprosy kiberbezopasnosti 3(31) (2019) 18-23. DOI: https://doi.org/10.21681/2311-3456-2019-3-1823

[11] T.Ya. Khabriyeva, Law Facing the Challenges of Digital Reality, Journal of Russian Law 6(9) (2018) 1. DOI: https://doi.org/10.12737/art_2018_9_1

[12] V.M. Koryakin, "Tsifrovizatsiya" obschestvennykh otnosheniy I vliyaniye na sostoyaniye korrupcii v voyennoy organizatsii gosudarstva, Voyennoe pravo 1(53) (2019) 217-228.

[13] E. Talapina, Law and Digitalization: New Challenges and Prospects, Journal of Russian Law 6(2) (2018) 1. DOI: https://doi.org/10.12737/art_2018_2_1

[14] Decree of the President of the Russian Federation dated 09.05.2017 No. 203 "On the Strategy for the Development of the Information Society in the Russian Federation for 2017 - 2030" // SZ RF. 2017. No. 20. Art. 2901.

[15] Order of the Government of the Russian Federation of July 28, 2017 No. 1632-r "On approval of the program" Digital economy of the Russian Federation "// SZ RF. 2017. No. 32. Art. 5138 (no longer valid).

[16] Order of the Government of the Russian Federation of 12.02.2019 No. 195-r "On recognizing as invalid the order of the Government of the Russian Federation of 28.07.2017 No. 1632-r" /// SZ RF. 2019. No. 8. Art. 803.

[17] Roscongress (2019) Smart regulation tools for the digital economy. https://roscongress.org/sessions/iif2019-instrumenty-umnogo-regulirovaniya-v-tsifrovoyekonomike/discussion/ Accessed 15 Dec 2019

[18] Passport of the national project "National Program" Digital Economy of the Russian Federation "(approved by the Presidium of the Council under the President of the Russian Federation for Strategic Development and National Projects, Minutes dated 04.06.2019, No. 7) http://www.consultant.ru/ Accessed 5 Jul 2019

[19] Passport of the federal project "Normative regulation of the digital environment" (approved by the Presidium of the Government Commission on Digital Development, the Use of Information Technologies to Improve the Quality of Life and Conditions for Doing Business, Minutes No. 9 dated May 28, 2019) http://www.consultant.ru/ Accessed 8 Sep 2019

[20] Draft Federal Law No. 747528-7 "On Amendments to Certain Legislative Acts of the Russian Federation in Connection with Improving Regulation in the Field of Electronic Signature" (as amended by the State Duma of the Federal Assembly of the Russian Federation, text as of 05.07.2019). http://www.consultant.ru/ Accessed 8 Sep 2019

[21] Draft Federal Law No. 747631-7 "On Amendments to Federal Laws "On Electronic Signatures", "On Protection of the Rights of Legal Entities and Individual Entrepreneurs in the Exercise of State Control (Supervision) and Municipal Control "and" On Accreditation in the National Accreditation System" http://www.consultant.ru/ Accessed 14 Sep 2019

[22] Federal Law of 18.03.2019, No. 34-FZ "On Amendments to Parts One, Two and Article 1124 of Part Three of the Civil Code of the Russian Federation" // SZ RF. 2019. No. 12. Art. 1224.

[23] Draft Federal Law No. 419059-7 "On Digital Financial Assets" (as amended, adopted by the State Duma of the Federal Assembly of the Russian Federation in the $1 \mathrm{st}$ reading on 05/22/2018) http://www.consultant.ru/ Accessed on 26 Jul 2018

[24] Draft Federal Law "On Amendments to the Federal Law" On Individual (Personified) Accounting in the Compulsory Pension Insurance System "(prepared by the Ministry of Labor of Russia) (as amended before submission to the State Duma of the Federal Assembly of the Russian Federation, text as of October 29, 2018) http://www.consultant.ru/ Accessed on 13 Dec 2018 
[25] Draft Federal Law "On Conducting an Experiment on Keeping Electronic Documents Related to Work Provided by Labor Law for Individual Employers" (prepared by the Ministry of Labor of Russia) (not included in the State Duma of the Federal Assembly of the Russian Federation, text as of May 16, 2019) http://www.consultant.ru/ Accessed 9 Jul 2019

[26] Draft Federal Law "On Experimental Legal Regimes in the Field of Digital Innovation in the Russian Federation" (prepared by the Ministry of Economic Development of Russia) (not included in the State Duma of the Federal Assembly of the Russian Federation, text as of 18.04.2019) http://www.consultant.ru/ Accessed on 9 Jul 2019

[27] Draft Federal Law "On Amendments to Part Four of the Civil Code of the Russian Federation" (prepared by the Ministry of Education and Science of Russia) (not included in the State Duma of the Federal Assembly of the Russian Federation, text as of 05/30/2019 http://www.consultant.ru/ Accessed on 9 Jul 2019

[28] Draft Federal Law "On Amendments to Part Four of the Civil Code of the Russian Federation" (prepared by the Ministry of Education and Science of Russia) (not included in the State Duma of the Federal Assembly of the Russian Federation, text as of 05/23/2019). http://www.consultant.ru/ Accessed on 11 Jul 2019

[29] Draft Federal Law "On Alternative Methods of Attracting Investments (Crowdfunding)" (prepared by the Ministry of Economic Development of Russia) (not included in the State Duma of the Federal Assembly of the Russian Federation, text as of 25.01.2018) http://www.consultant.ru/ Accessed on 9 Jul 2019

[30] P. Malkov, Normativnoye regulirovaniye tsifrovoy sredy. http://d-russia.ru/normativnoe-regulirovanietsifrovoj-sredy.html Accessed 12 Sep 2019

[31] O. Moskaleva, Opasnosti, kotorye tait tsifrovizatsiya, Zhilischnoye pravo 10 (2017) 63-72.

[32] A.A. Karzhia, Tsifrovizatsiya v prave I pravoprimeneniyi, Monitoring pravoprimeneniya 1 (2018) 36-41. 